\title{
Латынь и «словенский» в начальном образовании детей духовенства XVIII в.
}

\author{
ЕКАТЕРИНА КИСЛОВА \\ Кафедра русского языка, МГУ имени М. В. Ломоносова, \\ Ленинские горы, ГСП-1, RU-119991 Москва \\ E-mail: e.kislova@gmail.com
}

(Received: 22 June 2015; accepted: 3 September 2015)

\begin{abstract}
This paper deals with the issue of using Latin and "Slavensky" (Russian and Church Slavonic) languages in the primary ecclesiastical education in the 18th century. By the 1740s, seminary education in Latin had established itself in Russia. But primary teaching of reading and writing in Russian and Church Slavonic remained traditional until the end of the 18th century, regardless of where the teaching was taking place: at home or at a Russian school at a seminary. The Russian schools were organised for teaching illiterate or semiliterate children. But by the end of the 18th century, several seminaries attempted to reorganise them into ecclesiastical schools where Russian would be the only language of instruction. Junior classes at seminaries were fully focused on teaching Latin, however, Latin was by no means a complete replacement for Russian. The main method of instruction was translation, and the administrations of many seminaries demanded attention to the quality of students' translations into Russian. Therefore, Russian and Latin were functionally distributed in primary education. Only the Church Slavonic language was practically excluded from teaching after the primary courses of reading and church singing, and it preconditioned its conservation as a language used only for church services and led to the extinction of the hybrid form.

Keywords: the Latin language, the Russian language, 18th century, the Church Slavonic language, Russian seminaries
\end{abstract}

\section{1. Введение. Современные оценки «латинского образования» православного духовенства}

Настоящая статья посвящена положению латыни в начальном образовании детей духовенства XVIII в. Однако необходимо рассматривать позицию латыни не изолированно, а в соотнесенности с положением и статусом «природного языка» детей, который в церковных документах этого периода обычно называют «славенским» или «славено-российским» и в котором объединялись русский и церковнославянский языки (КисловА 2013: 103-104).

Ответ на вопрос о положении латыни в духовном образовании требует не только фактографического описания методов и способов преподавания, но и объяснения целей и задач изучения латыни будущими православными

* Работа выполнена в рамках гранта Президента РФ для поддержки молодых российских ученых (номер гранта МК-4924.2015.6). 
священниками. Этот вопрос неизбежно приводил исследователей к рассуждениям о том, как изучение латыни коррелировало с религиозными, идеологическими и националистическими представлениями эпохи.

До настоящего времени практически все исследователи в своих оценках «латинского образования» российского духовенства исходят из концепции, представленной в трудах П. Знаменского и Г. Флоровского: латинское образование духовенства, организованное по польско-латинской модели, объявляется причиной отказа от церковнославянского и русского языков, распространения «латино-протестантской схоластики» и в итоге - причиной отчуждения «богословской учености» от «церковного опыта» (ЗНАМЕНский 1881, Флоровский 1981). До сих пор во многих научных работах пишется о том, что «латинское образование» до начала XIX в. было настолько распространено в семинариях, что русский язык почти не использовался (СуховА 2013: $43)$ - что верно лишь отчасти и только для старших классов - философии и богословия.

Одной из наиболее значимых работ, посвященных латыни в учебных заведениях России XVIII в., является монография М. Окенфусса (см. OKENFUSS 1995). В ней сначала распространение, а затем уменьшение значения «латинского образования» в семинарской среде объясняется сменой национальных групп интеллектуалов: «украинских гуманистов»-русскими по происхождению выпускниками светских и церковных учебных заведений. В 1780-х гг. автор описывает настоящее изгнание латыни из духовного образования, связанное с деятельностью Платона Левшина: «....instructions and the disputations were now exclusively in Russian. Classical Greek became the chief language to be studied... and Latin was reduced to an ,elective“ class for the minority of students who continued studies to philosophy and theology» (OKENFUSS 1995: 219) - что, к сожалению, является преувеличением и не подтверждается фактами.

Подобные полярные позиции в оценке значения латыни в семинарском образовании очевидным образом возникают из-за проблем с сохранностью и доступностью архивных материалов семинарий (особенно провинциальных). Уже к середине XIX в., когда создавались первые научные описания истории семинарий, их авторы указывают на выборочную сохранность архивных данных XVIII в. (Никольский 1898: I-V). Поэтому все современные российские и европейские ученые (FREEZE 1977, Смолич 1996, Люьжин 2014 и др.) вынуждены опираться на труды XIX в. (ЗНАМЕНский 1881, СмиРнов 1855, Смирнов 1867 и др.).

Однако нельзя рассматривать положение латыни и «славенского» языков как одинаковое на протяжении всего курса обучения. В настоящей статье мы рассмотрим начальное образование детей духовенства, так как этот уровень был наиболее массовым, и поэтому вопрос о выборе языка и типа обучения здесь был наиболее острым.

В таком случае - как мы надеемся - нам удастся избежать крайностей в оценке церковного дискурса XVIII в. и показать относительно объективную социолингвистическую картину эпохи: функциональное распределение 
латыни и русского языка в образовании детей духовенства. Мы также будем использовать не только исторические описания семинарий, но и сохранившиеся архивные данные. Ряд связанных вопросов (латынь в средних и старших классах семинарий, оценка латинского образования представителями духовенства, уровень латинского языка учеников семинарий и т. д.) требует отдельного рассмотрения и поэтому будет опущен в настоящей работе.

\section{2. Латынь в России на рубеже XVII-XVIII вв.}

Историю преподавания латыни в России традиционно начинают с Петровской эпохи, однако необходимо помнить, что латинская культура XVIII века пришла в страну, в которой переводы с латыни не были редкостью (см. СоБолЕвский 1903).

K началу XVIII в. на территориях будущих Украины и Белоруссии уже появлялись учебные заведения, организованные по модели польских и западноевропейских коллегиумов (в первую очередь - иезуитских), в которых преподавание шло на латыни (ПосоховА 2011: 19-52, СуховА 2013: 4-16). Их распространение было связано со сложной конфессиональной и политической обстановкой XVI-XVII вв. (УСпЕнский 2002: 386-387).

Преподавание латыни не случайно распространялось вместе с регулярным «школьным» образованием: во всей Европе в это время латынь является языком обучения и, соответственно, тем языком, который ассоциируется в массовом сознании с образованием (WAQUET 2001: 7-40). Поэтому неудивительно, что даже в Москве XVII в. в различных греко-славянских школах так или иначе появляется латынь: Арсений Грек в 1649-1655 гг. преподает греческий и латынь, в библиотеке Типографской школы присутствуют греколатинские книги; в «Привилегии на Академию» 1668 г. латынь фигурирует наряду с греческим и «славенским» (Фонкич 2009: 63, 168, 207). Наряду с греческим, на латыни преподавали риторику, логику и физику братья Лихуды (Люьжин 2014: 126).

Почему же «греческая ученость» уже к 1720-м гг. вытесняется из духовного образования и ее позицию занимает латинская? ${ }^{1}$ «Латинская образованность» закономерно оказывалась противопоставленной грекофильской ориентации православной церкви и традиционной культуры Руси, однако коррелировала с латинофильской ориентацией Петра. В. М. Живов перечисляет целый ряд взаимосвязанных культурных противопоставлений этого периода: «...эллино-славянского учения и „славено-латинской” образованности [...], святоотеческого предания и эллинской мудрости, греко-российского православия и римско-европейского просвещения, церковной культуры и светской (секулярной) культуры, священства и царства, Церкви и Империи» (Живов 1996: 88). И латынь выступала здесь ключевым элементом новой культуры.

\footnotetext{
${ }^{1}$ Хотя в некоторых семинариях в 1720-х гг. еще сохранялось преподавание греческого, к концу 1730-х гг. оно почти везде прекратилось (Описание XIX: 616-620).
} 


\section{3. Распространение новой модели образования в России}

До реформ Петра образование духовенства было исключительно домашним. Приход был фактически наследственным владением (МАтисон 2009: 5-6), поэтому и обучение будущих священников становилось обязанностью отцов. Такое образование ограничивалось изучением богослужения «на практике»; дети священно- и церковнослужителей также овладевали навыками чтения, письма, церковного пения (о чем и свидетельствуют все источники, описывающие традиционную модель духовного образования; см., например, КРАВЕЦКИЙ 1999: 230-231, МиРОНОВ 2003: 98-100).

Латыни в таком образовании не было места в силу ее полной ненужности в повседневной жизни рядового священно- и церковнослужителя. Соответственно, подобное образование в глазах иностранцев, правительства и церковных иерархов, получивших «регулярное» образование, приравнивалось к неграмотности, ${ }^{2}$ а эталоном учебного заведения, отвечавшего представлениям и правительства, и членов Синода, была Киевская академия, ${ }^{3}$ по образцу которой создавались семинарии в России (Смолич 1996: 392). И логично, что самым ярким признаком учености нового, «петровского» типа в этой системе стало знание латинского языка. «Греческая ученость» не могла противостоять новым культурным тенденциям: так, Палладий Роговский, учившийся у Лихудов и затем в Западной Европе, возглавив Славяно-греко-латинскую академию, преподавал только на латыни (Люьжин 2014: 463).

Духовные учебные заведения создавались по модели западноевропейских коллегиумов и обычно имели следующие классы (Смолич 1996: 409):

a) начальные: инфима и фара (или аналогия), позже объединенные в информаторию. Затем два грамматических класса: низший (собственно класс грамматики) и высший (синтаксима или синтаксический класс). В задачу начальных классов входило подготовить учеников к восприятию наук, то есть научить латыни;

б) средние классы - класс пиитики (в разных семинариях в разное время мог присутствовать или отсутствовать) и класс риторики;

в) высшие классы - философии и богословия.

${ }^{2}$ Например, И. Фоккеродт пишет о Петровской эпохе так: «Nächst der Einführung dieser neuen geistlichen Reglementsform, und der damit verknüpften Anstalten, hat Petrus I. sich nichts mehr angelegen sein lassen, als seine Clerisei aus der vorigen Unwissenheit zu ziehen. Dieselbe war zu Anfang seiner Regierung weit gröber, als sie in Europa in den finstersten Seculis des Pabstthums gewesen sein kann... Wer lesen und schreiben konnte, und die Ceremonien der Kirche genau zu beobachten wusste, der hatte alle Requisita, die man nicht nur zu einem Priester, sondern auch zu einem Bischof erforderte» (HERRMANN 1872: 14).

${ }^{3}$ Духовные учебные заведения на протяжении XVIII - начала XIX века нередко меняли свой статус (архиерейские школы превращались в семинарии, семинарии получали статус академий, академии меняли названия и вновь становились семинариями, при семинариях открывались отдельные учебные заведения более низкого уровня, между ними происходило перераспределение классов и т. д.). Поэтому вынужденно мы будем называть каждое учебное заведение наиболее распространенным его названием (Славяно-греко-латинская академия, Киевская академия, Александро-Невская семинария и т. д.). 
В некоторых семинариях могла функционировать «русская школа», равная подготовительному классу.

Однако до конца 1730-х гг. эта модель оставалась скорее идеалом. До начала 1720-х гг. открывались внесословные школы при архиерейских домах, которые впоследствии могли быть преобразованы в семинарии или закрыты. ${ }^{4}$ В 1720 -х гг. в созданных учебных заведения ${ }^{5}$ преподавание оказалось сосредоточенным на обучении чтению и письму на церковнославянском и русском языках и мало отличалось от традиционной, «несеминарской» модели. Философия и богословие на латыни оставались недосягаемым идеалом: «...понеже совершеннейших учений богословского и философского, також и нужнейших языков искусства, еще за скудостью довольных к сему учителей, преподавать невозможно, того ради учить ныне в архиерейских школах... по... первого отроков учения книжицам, букварями именуемым...» (ПС3 VI: 697). После обучения букварю предлагалось учить детей «Славянской грамматике» Федора Поликарпова, арифметике и геометрии (ПС3 VI: 698). Рапорты архиерейских школ и первых семинарий показывают, что в преподавании также были распространены традиционные книги: азбука, Псалтырь и Часослов (Титлинов 1905: 376-377, Князев 1866: 5). Могли добавляться и другие предметы, например, музыка, живопись, греческий язык (Чистович 1857: 10-11).

Очевидно, новое образование в это время противопоставлялось традиционному по методике - как теоретическое практическому. Традиционная схема обучения описана в работах Б. А. Успенского и А. Г. Кравецкого: оно до конца XIX века состояло в многократном прочитывании и заучивании наизУсть основныХ церковНославянскиХ текстов (УСПЕНСКИЙ 1997, КРАВЕЦКИЙ 1999: 228-242). В противоположность данной методике, в государственных учебных заведениях учителя должны были не только учить читать по-церковнославянски, но и с самого начала преподавать учащимся некоторый набор теоретических знаний о языке,${ }^{6}$ причем грамматический подход должен был внедряться с самого начала как залог правильной основы дальнейших знаний: «славенская грамота» «в детском научении требует от учащаго весьма правильно грамматичного от фундамента ко чтению и письму научением вкоренения» (Синод 1722: 172).

Внедрение грамматического подхода в преподавании церковнославянского языка происходило в начале XVIII в. с большим трудом и требовало административных мер. Так, Феодосий Яновский, архиепископ Новгородский, в 1722-1723 гг. указывал Синоду на необходимость отбора учителей,

${ }^{4}$ Одним из первых учебных заведений нового типа стала школа, организованная Димитрием Ростовским; она состояла из трех классов, в которых преподавались русская азбука (чтение и письмо), латынь и греческий, однако эта школа просуществовала всего три года с 1702 по 1705 гг. (Сухова 2013: 28).

${ }^{5}$ К 1723 г. в России было открыто восемь духовных учебных заведений: АлександроНевская семинария в Санкт-Петербурге, семинарии в Новгороде, Нижнем Новгороде, Казани, Суздале, Коломне, Вятке, Холмогорах.

${ }^{6}$ О сосуществовании этих моделей обучения в XVI-XVII вв. на юго-западных территориях см. МЕЧКОВСКАЯ 1985. 
знающих грамматику, и запрещение преподавать всем остальным: «по той Духовнаго регламента силе заказано в епархии моей, дабы кроме оного славенскую грамматику окончавших никого учить никто отнюдь не дерзал, а учили б всех учиться хотящих оные грамматисты, дабы правильное учение во всех возрастало» (РГИА, ф. 796 оп. 4 ед. хр. 440). Он также указывает, что в заведенных им школах с «искусными учителями» обучается около 500 детей духовенства и всего 30 «разночинцев», а «светские обыватели» «детей своих по прежнему обучают невеждами», т. е. по традиционной схеме (РГИА, ф. 796 оп. 4 ед. хр. 440). Действительно, «освидетельствование» учителей, проведенное в 1722 г. в Санкт-Петербурге по его же инициативе, показало, что почти все они учили детей по традиционной модели - «словенского чтения, псалмов и молитв и писания, ничтоже грамматического разума и правописания сами знающии» (Синод 1722: 176). При организации семинарий в провинциальных городах часто не находилось учителей, знакомых с новыми методиками, поэтому Синод предписал отсылать для обучения в Новгород из каждой епархии по 3 человека «остроумных и книжному учению искусных» для обучения (АГнцев 1889: 12).

Внедряемое таким образом грамматическое обучение церковнославянскому явным образом соотносится с грамматическим методом преподавания латыни. Если церковнославянский язык был интуитивно понятен носителям русского даже в рамках традиционной модели обучения, то применительно к латыни обучение без грамматической основы не могло быть успешным. И как латынь выступала в качестве эталонного языка образования, так и методы ее преподавания становились моделью для преподавания других языков и переносились в том числе на церковнославянский.

\section{4. Распространение «латинского образования»}

Несмотря на сложности, связанные с организацией духовных учебных заведений, уже в середине 1720-х гг. в семинариях Казани, Нижнего Новгорода, Коломны, Рязани начинается начальное преподавание латыни («наука елементарная латинская»), а в Тверской, Новгородской и Александро-Невской семинариях, кроме латыни, преподается также греческий (ср. Титлинов 1905: 376-377, Описание XIX: 616-620). К концу 1720-х гг. лучшие провинциальные семинарии открывают классы поэтики (Нижегородская семинария) и даже риторики (Новгородская семинария). Полный курс в это время был только в Московской Славяно-греко-латинской академии, но даже в провинциальных семинариях постепенно становилось все больше учеников, в той или иной степени освоивших латынь, что сделало возможным окончательное закрепление новой, ориентированной на латынь, модели духовного образования.

В конце Аннинского царствования в различных указах 1737-1738 гг. описывается устройство семинарий, в которых «надлежит обучать на российском языке грамоте, а потом грамматике, риторике и других вышних наук» (ПС3 Х: 257); в указе об основании семинарии в Троицкой лавре указывается 
необходимость обучения «латинского, греческого, и если возможно, и еврейского языков, начав от грамматики даже до риторики, философии и богословии» (ПС3 Х: 620). И если грамматическое учение еще могло преподаваться применительно к церковнославянскому языку, то риторика, а тем более философия и богословие как учебные предметы были актуальны именно на латыни и требовали ее предварительного освоения (СтрАтий 1982, Суториус 2008).

С этого момента идейным ядром духовного образования становится «латинская образованность». Косвенно об этом свидетельствуют отцы, отдающие в 1740-1750-х гг. своих детей в семинарии: в своих подписках, согласно формуляру, они указывают в качестве единственной цели направления детей в семинарии обучение «латинскому (реже греколатинскому) диалекту» (РГБ, ф. 277 ед. хр. 1, 2 и др., ф. 757 к. 2. д. 2; РГАДА, ф. 1189 ед. хр. 332 и др.), и только в 1770-х гг. появится формулировка «для обучения разным наукам» (РГБ, ф. 277, ед. хр. 5).

И хотя этот тип школ испытывает колоссальные сложности (проблемы с финансированием, отсутствие учителей и книг, бегство учеников, социокультурное неприятие семинарий отцами - см. Смолич 1996: 394-395), к началу 1740-х гг. все-таки большая часть созданных семинарий имеет в качестве старшего класс поэтики (семинарии в Холмогорах, Рязани, Новгороде) или риторики (в Вологде, Вятке, Пскове, Переславле). В Смоленске и Казани появляется первый из высших классов - класс философии. Очевидно, что как раз к началу 1740-х гг. лучшие ученики, начавшие твердить «латинские елементари» в начале 1730-х гг., выучили латынь настолько, что они смогли осваивать на этом языке поэтику, риторику и философию. ${ }^{7}$ Однако до конца XVIII в. только сравнительно небольшая часть детей духовенства была охвачена «латинским» семинарским образованием и еще меньшая была в состоянии завершить полный курс обучения (на примере Твери статистику см. МАтисон 2009: 113-124; данные по Пскову - Князев 1866; фрагментарные данные по Сибири - ПоБЕдинский 1896).

\section{5. Начальное обучение грамоте}

Отныне должно было усилиться преподавание латыни и в начальных классах семинарий: необходимо было начинать изучение иностранного языка как можно раньше, поэтому обучение базовой грамотности на родном языке вновь отодвигалось на досеминарский уровень. В указе 1738 г. о создании Троицкой семинарии содержится требование принимать в семинарию

${ }^{7}$ На успешность создания учебных заведений с латинской моделью преподавания неизбежно влияли географическая близость к столице, богатство епархии и наличие у семинарии материального обеспечения, возможность быстрого получения из столиц учебников, уровень образования правящих архиереев, их желание заниматься проблемами семинарии и т. д. Г. Фриз относит закрепление латинской модели к 1760-м гг. (FREEZE 1977: 94), однако уже в 1739 г. латынь не преподавалась только в школах 4 епархий: Рязанской, Суздальской, Тобольской и Иркутской; в остальных епархиях латинское образование было заведено и более или менее успешно функционировало (Описание XIX: 616-620). 
детей 10-15 лет, «которые уже обучены читать и писать в русском языке» (ПС3 X: 620). Дети, которые не были достаточно обучены грамоте (чтению на церковнославянском и письму), возвращались к отцам на определенный срок (1-3 года) для доучивания.

Однако почти все провинциальные семинарии сохраняли в своем составе «русскую школу» (в разных городах называвшуюся славяно-российской, писцовой, писарской, заправной, сиротской, школой русской грамматики и т. д.), в которой неграмотные дети обучались чтению и письму, а у грамотных детей эти навыки доводились до уровня, достаточного для дальнейшего обучения в семинарии. Предполагалось, что русские школы предназначены для сирот и детей из самых бедных семей, однако это правило редко выполнялось. ${ }^{8}$ В некоторых случаях функцию русской школы могла исполнять частная городская школа традиционного типа: например, в Воронеже в 1740-х гг. неграмотные дети попадали для начального обучения азбуке, Псалтыри и Часослову к дьячку Федору Иванову (Никольский 1898: 36-37).

Русские школы при семинариях были наиболее низкими по статусу и при этом самыми массовыми по числу учеников: так, в Воронежской семинарии в 1738 г. в славяно-российской школе было 407 учеников, а в славяно-латинской - 120 (Титлинов 1905: 393); в Псковской семинарии в 1740 г. в славянороссийской школе было 114 учеников, в фаре 35 (Князев 1866: 7-9).

Обучение в русской школе оставалось вполне традиционным: преподавание шло по азбуке, букварю, Псалтыри и Часослову, во второй половине века могли добавляться арифметика, катехизис, церковный устав, священная история, нотное пение, скоропись, «составление церковных росписей, метрик и извлечение из них кратких табелей» и другие предметы (ПоБЕдинский 1896: 46, СмиРнов 1855: 308, Агнцев 1889: 114).

Таким образом, начальное обучение оставалось для ребенка вполне традиционным независимо от того, где он учился - дома или в русской школе при семинарии. Оно включало в себя обучение чтению на церковнославянском языке (по азбуке, букварю, Псалтыри и Часослову) и обучение письму на русском языке (что, вероятно, до последней четверти XVIII в. было эквивалентно обучению скорописи). Требование Синода обучать чтению не только церковнославянской, но и гражданской печати появилось только в 1781 году и сопровождалось рассылкой по епархиям новых гражданских азбук (см. НечАевА 2005: 19). Очевидно, что и до этого семинаристы умели читать гражданскую печать, так как многие книги и учебники, использовавшиеся в средних и старших классах, были напечатаны гражданским шрифтом, но

\footnotetext{
${ }^{8}$ Например, в 1742 году епископ Стефан Калиновский потребовал оставить в русской школе Псковской семинарии только сирот и детей из самых бедных семей, а всех остальных вернуть отцам для обучения грамоте (КнязЕВ 1866: 15), в 1768 году русская школа была объединена с классом информатории (КнязЕв 1866: 32), а в 1780 году вновь была сделана попытка организовать отдельную школу для сирот, в которой должны были учить читать по-русски и петь, а наиболее успешные ученики могли также учиться читать и писать на латыни (КнязЕВ 1866: 28).
} 
с 1781 г. преподавание гражданской азбуки стало обязательно именно в начальных классах семинарии.

В редких случаях отцы, уже получившие семинарское образование, заранее начинали учить детей латыни: например, священник Успенского собора Кремля, известный проповедник Стефан Левицкий в 1750 г. свидетельствовал о том, что его сын Иван, отправляемый в Славяно-греко-латинскую академию, «обучен российскому и латинскому чтению и писанию» (РГБ, ф. 277. ед. хр. 2, л. 20).

\section{6. Русские школы к началу XIX в.}

К концу XVIII в. русские школы взяли на себя не столько функцию подготовки детей к «латинским наукам», сколько обучение неспособных, тех, кто не мог освоить латынь и вынужденно годами оставался в начальных классах. Указ Синода от 25 августа 1800 г. предписал готовить неспособных к латыни к причетнической должности: «обучать их... в Русской школе, которой, ежели где их в семинариях ныне нет, везде непременно завести, чтению, церковному уставу и кругу, нотному пению, также писать, и чтобы они знали катехизис и священную историю, а равно занимать и другими относящимися к той должности, к коей предуготовляются, предметами...» (ПСЗ XVII: 278).

18 марта 1803 г. последовал еще один указ, предписывавший создавать русские школы по программе, разработанной Амвросием (Подобедовым). Предполагалось создание 3 классов, равных 5 годам обучения, и преподавание следующих предметов (РНБ ф. 522 ед. хр. 209 л. 170):

a) 1 класс (1 год обучения): чтение на церковнославянском и русском языках («славянской и гражданской печати»), чистописание, обиходное пение, изучение «Краткой российской грамматики» Е. Б. Сырейщикова.

б) 2 класс (2 года обучения): всеобщая и российская история, география, арифметика, пасхалия.

в) 3 класс (2 года обучения) обладал наиболее насыщенной программой: предполагалось обучение детей краткой логике (видимо, по книге «Краткая логика, или Умословие, служащее в пользу российского юношества», Москва, 1788), риторике на русском языке (по книге Гальена де Сальморана «Краснословие или Риторика в кратких правилах для всеобщего употребления», Санкт-Петербург, 1785), пространному катехизису, церковному уставу; изучались книги «О должностях человека и гражданина» (Санкт-Петербург, 1783), «О должностях пресвитеров приходских» Парфения Сопковского и Георгия Конисского (Москва, 1796), «Краткое руководство к чтению книг Ветхого и Нового Завета» Амвросия Подобедова (Москва, 1779).

Граница между русскими школами и семинариями очевидным образом проводилась по способностям учеников к латинскому языку: «...священнои церковнослужительские дети... неспособные к продолжению высших наук и изучению латинского языка, на котором они обыкновенно преподаются, 
могут, оставаясь при своем природном, образовать способности ума своего, и чрез то с пользою послужить церкви» (ПС3 XVII: 502). Выпускники таких русских школ получали право не только занимать причетнические должности, но и учить детей в приходских училищах - и даже могли становиться священниками в сельских церквях (ПСЗ XVII: 502).

Разумеется, не везде русские школы были так организованы и не все эти предметы действительно преподавались. Например, в Пскове первый класс русской школы был соединен с информаторией, причем изучение русской грамматики было перенесено во 2 класс, по-видимому, так и не открывшийся (Князев 1866: 31-32). В итоге в русской школе Псковской семинарии традиционно обучали чтению гражданской и церковнославянской печати, русскому чистописанию, краткому катехизису, церковному пению и арифметике (Князев 1866: 40).

В Тамбове классы были закрыты за неимением учеников (ЗНАмЕнский 1881: 743). Однако в Троицкой, Казанской, Рязанской и Воронежской и некоторых других семинариях русские школы в целом соответствовали плану Амвросия Подобедова и просуществовали до 1808-1816 гг. (СмиРнов 1867: 325-326, МожАРОВСКИЙ 1877: 22-23, АГнцЕВ 1889: 125, НикОЛЬСКИй 1898: 172-173).

Фактически в первом десятилетии XIX столетия в русских школах, организованных по плану Амвросия (Подобедова), оказалось сосредоточено то практическое духовное образование, которое пользовалось спросом в среде рядового духовенства - и с которым не могло конкурировать ставшее уже традиционным латинское семинарское образование. Священно- и церковнослужители предпочитали отдавать детей только в «русскую школу», где дети получали достаточный объем знаний на родном языке и избегали «латинской науки».

В 1816 году в Казани архиепископ Амвросий (Протасов) потребовал закрыть «расширенную» русскую школу и сохранить класс только для обучения неспособных со следующей аргументацией: «Русские классы совершенно почитаю я не только бесполезными, но и вредными просвещению духовенства; ибо очень приметно, что духовные, вместо того, чтобы записывать детей своих в академию для окончания академического курса, и тем сделать их со временем достойными служителями церкви, записывают их в русские классы; и так делаются учеными, но не учеными. Почему и нужно их уничтожить, как не отвечающие и новому уставу, кроме первого, который должен оставаться только для тех учеников низших классов, кои неспособны окажутся к учению, и притом с тем, чтобы они из оного выходили только на причетнические места» (МожАровский 1877: 45-46).

Еще раньше, в 1808 году, такая же судьба постигла успешную русскую школу в Рязани: она была преобразована в два класса, из которых первый «для учеников к латинским школам приуготовляемых», а второй оставался «единственно русским для готовящихся на причетнические места» (АГнцеВ 1889: 125). 


\section{7. Начальные классы семинарий}

Начальные классы семинарий неизбежно оказывались двуязычными: преподавание латыни на начальном этапе должно было опираться на родной детям язык. Однако после информатории русский язык уже не является предметом обучения: все средние классы были посвящены изучению латыни и ориентированы на латынь. Традиционно началами латыни овладевали по грамматике Э. Альвара, во второй половине века использовались также «Краткая грамматика латинская...» В. Лебедева, «Латинская грамматика» Н. Н. Бантыш-Каменского и др. Но сохранилось мало учебных материалов этих классов, показывающих реальное употребление русского языка в процессе обучения детей латыни.

Редким примером учебных материалов первой половины XVIII в. можно считать «Трактаты окупаций домашних и ексерцицей школьных» Рафаила Заборовского (РНБ, ф. 577, ед. хр. 77). Это учебные тексты классов инфимы, грамматики, синтаксимы и поэтики, которые использовались в Славяногреко-латинской академии в 1714-1716 гг. Все они, кроме текста поэтики, двуязычные - одно и то же упражнение представлено на латыни и на русском. И только поэтика дана исключительно на латыни, что соответствует традиции латинских поэтик и риторик, развивавшейся в Киевской академии и перенесенной в российские семинарии (ВомПЕРСКИй 1988: 29-38, СтРАТИй и др. 1982).

Сходную картину латино-русского двуязычия в начальных классах мы видим в материалах Новгородской семинарии даже в первом десятилетии ХIX в. (РНБ, ф. 522, ед. хр. 209): в 1802 г. в информатории преподавали «чистописание латинское и российское, правописание российское и сколько можно латинское, начальные основания латинской грамматики» (л. 91). В двух грамматических классах (высшем и низшем) изучали латинскую грамматику и читали латинских авторов (Юлия Цезаря, Цицерона, Корнелия Непота, басни Федра и др.). Ученики тренировались в переводе периодов с русского на латынь и обратно, а также заучивали наизусть образцовые диалоги на латыни - «Colloquia Scholastica» Матурина Кордерия (Maturinus Corderius). В этих классах учителя уже должны были общаться с учениками преимущественно на латыни: «для приучения учеников к латинскому разговору по большей части и сами [учителя] говорят по-латине» (л. 90 об.).

С небольшими вариациям так учились во второй половине - конце XVIII века в Воронежской, Рязанской и Владимирской семинариях (Никольский 1898: 147-148, АГнцев 1889: 114-115). В последней в информатории обучали чтению и чистописанию на латыни и русском, изучали начальные правила грамматики, читали малый катехизис и заучивали «латинские вокабулы» наиболее употребительные слова. В классе грамматики продолжали изучать русскую грамматику, делали переводы с русского на латынь, а с середины года изучали «школьные разговоры с разбирательством этимологических и грамматических правил» (НАдЕждин 1875: 105), причем в общении с учени- 
ками учитель переходил на латынь. В синтаксиме и учитель, и ученики должны были общаться уже только на латыни. Ученики изучали латинскую грамматику Э. Альвара, делали переводы с латыни на русский, читали латинские разговоры Эразма и Кастеллиона, заучивали более сложные слова из Целлариева лексикона и начинали сочинять латинские стихи (НАдЕждин 1875: 104 105). В некоторых семинариях ученики заучивали наизусть всю латинскую грамматику на русском языке (например, грамматику Бантыш-Каменского) не только латинскую, но и русскую часть (АГнцев 1889: 114-115).

\section{8. Выводы}

Итак, на протяжении всего XVIII в. начальное обучение «славенской» грамоте мало отличалось от традиционного допетровского. Преподавание по допетровским «славянским» грамматикам (М. Смотрицкого, Ф. Поликарпова, И. Максимовича) могло сохраняться в архиерейских школах или семинариях, но не было повсеместным; в конце XVIII - начале XIX в. распространяются грамматики русского языка.

Полный отказ от употребления русского языка был теоретически возможен только в средних и старших классах, в которых ученики уже владели латынью относительно свободно. Как это было реализовано на практике, сильно варьировалось в зависимости от способностей учеников, уровня подготовки учителей, порядков, заведенных в семинариях правящими архиереями. Хотя классы поэтики, риторики, философии и богословия в исходной украино-польской модели были ориентированы полностью или преимущественно на латынь, со второй половины века живые славянские языки все активнее включались в процесс обучения: раньше всего - в классах поэтики и риторики, позже всего - в классе богословия.

В 1786 г. был издан указ о народных училищах, распространенный на семинарии, который усиливал преподавание не только предметов на русском языке, но и самого русского языка. Он способствовал увеличению роли русского даже в старших классах семинарий (ЗнАмЕнский 1881: 792), однако не мог поколебать позиции латыни в начальных и средних классах. Ректор и префект Троицкой семинарии не рекомендовали усиливать в начальных классах обучение русскому языку: «...ежели принять правило народных училищ в рассуждении учения российской грамоте и писанию, то предвидится из того впредь последовать препятствие успехам в латинском языке, ибо те, которые должны будут учиться наперед российской грамоте и писанию, к учению латинского языка будут приступать уже гораздо позже» (Смирнов 1867: 328).

Таким образом, в начальных классах семинарии русский язык даже после 1786 г. не стал самостоятельным предметом обучения, оставаясь вспомогательным этапом перед переходом к латинскому образованию.

Но основным методом преподавания иностранных языков в это время был перевод, поэтому зоной практического совершенствования русского языка как раз и становились учебные переводы, которые на протяжении всего 
обучения выполнялись в классах, посвященных изучению латыни, а также других языков: греческого, еврейского, французского и немецкого. Причем на качество русского языка в переводах в семинариях всегда обращали внимание. Например, в начальных классах Рязанской семинарии для перевода давались простые тексты, причем их нужно было «приноравливать к слововыражению языка, на который делался перевод, „не допуская только дикости, весьма противной или русскому, или латинскому языку“» (АГнцЕВ 1889: 115). Платон Левшин неоднократно распоряжался обращать внимание на качество переводов и их язык (Смирнов 1867: 310). Во второй половине века регулярно распоряжались следить за правильностью русской орфографии и церковнославянского чтения воронежские архиереи (Никольский 1898: 168170). Правильное произношение особенно важно было в регионах, где семинаристы были носителями украинского языка и южнорусских диалектов (ЗНАмЕНский 1881: 736), но не только: в начале XIX в. в Александро-Невской семинарии правильному произношению и декламации на русском языке студентов обучал актер А. С. Яковлев (Чистович 1857: 126).

Таким образом, «славенский» и латынь в начальных классах семинарий распределялись по той функции, которую они выполняли в жизни учеников: русский был средством обучения латыни, которая являлась «ключом к высшим наукам», однако благодаря переводному методу ученики продолжали совершенствоваться в русском языке на практике - с неизбежной латинской интерференцией. И только церковнославянский фактически не преподавался после начального обучения чтению и церковному пению, что предопределило его консервацию в качестве исключительно богослужебного языка и привело к исчезновению гибридной формы.

\section{Литература}

АГНЦЕв 1889 = АГНЦЕВ Д. История Рязанской духовной семинарии. Рязань, 1889.

ВишнеВСКИй 1903 = ВишнЕВСКий Д. Киевская академия в первой половине XVIII столетия. Новые данные, относящиеся к истории этой Академии за указанное время. Киев, 1903.

Живов 1996 = Живов В. М. Язык и культура в России ХVIII века. Москва, 1996.

ЗНАМЕНСКИЙ 1881 = ЗНАМЕНСКИЙ П. Духовные школь в России до реформы 1808 года. Казань, 1881.

КисловА 2013 = КисловА Е. И. «Природный язык» и язык обучения в духовном образовании XVIII века. В кн.: UlRICH S., Kislova E., KUBICKA E. (Hrsg.) Beiträge der Europäischen Slavistischen Linguistik. POLYSLAV 16. München-Berlin-Washington, 2013. 102-108.

КнязЕВ 1866 = КнязЕВ А. Очерк истории Псковской семинарии от начала до преобразования ее по проекту 1814 года. Москва, 1866.

КРАВЕЦКИЙ 1999 = КРАВЕЦКИЙ А. Г. Литургический язык как предмет этнографии. В кн.: ЛЕвИЕВСКАЯ Е. Е. (ред.) Славянские этюды. Сборник к юбилею С. М. Толстой. Москва, 1999. 228-242.

Люьжин 2014 = Люьжин А. И. История русской школьл. Т. 1. Русская школа ХVIII столетия. Москва, 2014. 
МАтиСОН 2009 = МАТисон А. В. Православное духовенство русского города ХVIII века. Генеалогия священно-иерковнослужителей Твери. Москва, 2009.

МЕчКОВСКАЯ 1985 = МЕчКОВСКАЯ Н. Б. Архаическое и новое в Лингвистическом сознании одной эпохи (к характеристике восточнославянских грамматик XVI-XVII вв.). Slavica Tartuensia 1 (1985): 15-24.

Миронов 2003 = Миронов Б. Н. Социальная история России периода империи (XVIIIначало $Х Х$ в.). Санкт-Петербург, 2003.

МожАРОВский $1877=$ МожАРОВский А. П. Старая Казанская академия. В кн.: Чтения в императорском обществе истории и древностей Российских при Московском университете. Кн. 2. Москва, 1877. 1-131.

НАДЕЖДИН 1875 = НАДЕЖДИН К. История Владимирской духовной семинарии (с 1750 года по 1840 год). Владимир, 1875.

НечАЕвА 2005 = НечАЕВА Л. В. Православные духовные школы Западной Сибири в XVIII веке. К 300-летию духовной школы в Сибири. Известия Российского государственного педагогического университета им. А. И. Гериена. Т. 5. Вып. 11. Санкт-Петербург, 2005. 15-31.

Никольский 1898 = Никольский П. История Воронежской семинарии. Ч. 1. Воронеж, 1898.

Описание XIX = Описание документов и дел, хранящихся в архиве Святейшего Правительствующего Синода. Т. ХІХ. 1739 г. Санкт-Петербург, 1913.

ПоБЕДИНСКИЙ 1896 = ПоБЕДИНСКИй М. Старинные Томские духовные иколь (17461820 г2.). Томск, 1896.

ПСЗ VI = Полное собрание законов Российской империи. T. VI. 1720-1722 гг. СанктПетербург, 1830.

ПСЗ Х = Полное собрание законов Российской империи. Т. Х. 1737-1739 гг. СанктПетербург, 1830.

ПСЗ XVII = Полное собрание законов Российской империи. Т. XVII. 1802-1803 гг. Санкт-Петербург, 1830.

Синод 1722 = Описание документов и дел, хранящихся в архиве Святейшего Правительствующего Синода. 1722 г. Т. 2. Ч. 2. Санкт-Петербург, 1878.

СмиРнов 1855 = СмиРнов С. История Московской Славяно-греко-латинской академии. Москва, 1855.

СмиРнов 1867 = СмиРнов С. История Троицкой лаврской семинарии. Москва, 1867.

Смолич 1996 = Смолич И. К. История русской цееркви. 1700-1917. Кн. 8. Ч. 1. Москва, 1996.

СоБОЛЕвСкий 1903 = СоБолЕвСкий А. И. Переводная литература Московской Руси XIV-XVII веков. Санкт-Петербург, 1903.

СТРАТИЙ и др. 1982 = СтрАТИй Я. М., ЛитвИновА В. Д., АНДРУШКО В. А. Описание курсов философии и риторики профессоров Киево-Могилянской академии. Киев, 1982.

СутоРиус 2008 = СутоРиус К. В. Источники по истории преподавания православного латиноязычного богословия в России в первой половине XVIII века. Диссертация на соискание ученой степени кандидата исторических наук. Санкт-Петербург, 2008.

Сухова 2013 = СуховА Н. Ю. Духовные иколь и духовное просвещение в России (XVII - начало XX в.). Санкт-Петербург, 2013.

Титлинов 1905 = Титлинов Б. В. Правительство Анны Иоанновны в его отношениях к делам православной цееркви. Вильна, 1905. 
УСПЕнский $1997=$ УспЕнский Б. А. Старинная система чтения по складам (глава из истории русской грамоты). В кн.: УСпЕнский Б. А. Избранныле труды. Т. 3. Общее и славянское языкознание. Москва, 1997. 246-267.

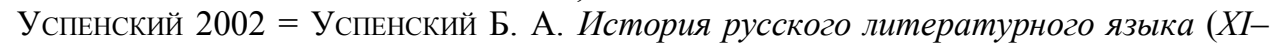
XVII в.). Москва, 2002.

ФлОРОВСКий 1981 = ФлоРовский Г. Пути русского богословия. Paris, 1981.

Фонкич 2009 = Фонкич Б. Л. Греко-славянские школы в Москве в XVII веке. Москва, 2009.

Freeze $1977=$ Freeze G. L. The Russian Levites. Parish Clergy in the Eighteenth Century. Cambridge-London, 1977.

HERRMANN 1872 = HERRMANN E. (Hrsg.) Russland unter Peter dem Grossen. Nach den handschriftlichen Berichten Johann Gotthilf Vockerodt's und Otto Pleyer's. Leipzig, 1872.

OKenfuss 1995 = OKenfuss M. J. The Rise and Fall of Latin Humanism in Early-Modern Russia. Pagan Authors, Ukrainians, and the Resiliency of Muscovy. Leiden-New YorkKöln, 1995.

WAQUET 2001 = WAQUET F. Latin or The Empire of a Sign: from the Sixteenth to the Twentieth Centuries. London-New York, 2001. 